\title{
Corporate Governance and Value Relevance in Indonesia Manufacturing Companies
}

\author{
Yunika MURDAYANTI ${ }^{1}$, I Gusti Ketut Agung ULUPUI ${ }^{2}$, Indra PAHALA ${ }^{3}$, Susi INDRIANI ${ }^{4}$, S. SUHERMAN $^{5}$
}

Received: August 01, 2020 Revised: September 20, 2020 Accepted: October 05, 2020

\begin{abstract}
This study aims to describe the role of corporate governance as a moderator in electronic financial disclosure that adopts Extensible Business Reporting Language (XBRL) and Company Characteristics on value relevance. The population in this study was all manufacturing companies listed on the Indonesia Stock Exchange from 2017 to 2018, totaling 166 companies. The sampling technique used purposive sampling method, namely, manufacturing companies that publish fully audited financial statements by December 31 of the year 2017-2018. The method used in this research is a quantitative description using the financial statements of manufacturing companies listed on the Indonesia Stock Exchange that have adopted XBRL during the 2017-2018 period. The data analysis method used is multiple regression analysis with moderating variables. The results of this study show a negative and insignificant effect of XBRL on value relevance, a significant negative effect of size on value relevance, a positive and insignificant effect of growth on value relevance, and a significant positive effect of profit on value relevance; meanwhile, corporate governance moderation variable has an insignificant effect in all hypotheses. Suggestions are to increase the number of variables that have an important role in value relevance and expand the number of research objects to be compared.
\end{abstract}

Keywords: XBRL, Company Characteristics, Value Relevance, Corporate Governance

JEL Classification Code: M40, M41, M48

\section{Introduction}

The development of IT or digitalization is the result of the technological revolution, especially information, which has changed almost all aspects of life, including the running of in the business world. The Industrial Revolution 4.0 is marked by significant technological advance, which is the emergence of artificial intelligence technology has changed many things in life, including eliminating many activities that were previously done

${ }^{1}$ First Author and Corresponding Author. Lecturer, Faculty of Economics, Universitas Negeri Jakarta, Indonesia [Postal Address: Pesona Khayangan V Blok N No.7 JI Ir Juanda Depok, West Java, 16411, Indonesia] Email: yunika_murdayanti@unj.ac.id

${ }^{2}$ Lecturer, Faculty of Economics, Universitas Negeri Jakarta, Indonesia. Email: Igka-Ulupui@unj.ac.id

${ }^{3}$ Lecturer, Faculty of Economics, Universitas Negeri Jakarta, Indonesia. Email: indrapahala@unj.ac.id

${ }^{4}$ Lecturer, Faculty of Economics, Universitas Negeri Jakarta, Indonesia. Email: sisusie.indriani@unj.ac.id

${ }^{5}$ Lecturer, Faculty of Economics, Universitas Negeri Jakarta, Indonesia. Email: suherman@unj.ac.id

(C) Copyright: The Author(s)

This is an Open Access article distributed under the terms of the Creative Commons Attribution Non-Commercial License (https://creativecommons.org/licenses/by-nc/4.0/) which permits unrestricted non-commercial use, distribution, and reproduction in any medium, provided the original work is properly cited. by humans. Indonesia is considered to be an ASEAN country that has high optimism in terms of readiness to implement Industry 4.0. Artificial intelligence does not only reduce errors in activities that were previously handled by humans, but for companies, it is the achievement of effectiveness and efficiency in their operations (Cahyadi, 2019).

Along with the development of Internet in the era of the Industrial Revolution 4.0, as it is today, the practice of corporate financial reporting through the World Wide Web is increasingly common and has become one of the main sources of information related to companies. Reporting via the Internet offers many benefits for companies and users of financial reports, one of which is the ease of disseminating and accessing financial information, and increasing the timeliness of reporting (Mahardika, 2018). It is hoped that information that is owned by a company or a country can be used and processed quickly and efficiently if the information is presented in the same language format. Therefore, to realize this desire and also be able to support the creation of facilities in the implementation of business intelligence, and make it easier for investors and regulators to access and process the data needed for decision-making, an integrated solution is needed in standardizing the language of reporting information, in this case, Extensible Business Reporting Language (XBRL). 
Sari et al. (2016) research company characteristics that influence the quality of the value relevance of the information provided to investors. Companies that have large assets will be relatively more stable and more able to generate profits compared to small companies. Cautious investors (riskaverse) tend to invest in large companies because they have a smaller level of risk. Masrifa's (2016) research shows that a company is founded with the hope of being sustainable (going concerned) and not for the short term. Investors expect the company to grow and develop well to provide good value, wealth and benefits to investors. The main objective of the company is no longer only to maximize profits, but rather to maximize firm value. Maximizing company value is very important for a company because company owners or shareholders will become richer, more prosperous. Company characteristics are one of the factors affecting firm value. A characteristic is something specific possessed by a company that can be developed for its interests. Zamroni (2018) shows, based on the context of obligations, that XBRL can improve the quality of financial information and increase the accuracy of decisions among users to reduce information asymmetry; this is specified for large-size companies compared to smalland medium-size companies. Gandasari's research (2015) states that, with the application of Corporate Governance, decision-making will be optimal, this is supported by good company characteristics that can provide value to the company.

Disclosure of $\mathrm{CG}$ in annual reports can reduce information asymmetry to produce quality reports. Besides, other factors can produce quality financial reporting. One of them is the company's internal factors related to the inherent factors or intrinsic factors inherent in the company itself, which in various studies are referred to as specific factors or company characteristics. Mahardika (2018) corrects previous research by adding the influence of the moderating variable corporate governance $(\mathrm{CG})$ on the relationship between XBRL adoption and information asymmetry. The moderating variable was added because $C G$ was a variable that, in previous studies, had a direct effect on information asymmetry. Companies with good CG are estimated to have good financial reporting quality so that their financial reports are more transparent and the information asymmetry for these companies decreases. Cormier (2018) states that earnings tend to be high quality, that is, relevant and reliable if there is a strong CG, which is a situation that will attract financial analysts and reduce information asymmetry. In the context of the existence of XBRL extensions, it becomes less necessary and less relevant for revenue assessment. The XBRL extension tends to be more relevant in the context of weak CG, for example, to act as a substitute for less effective governance mechanisms that reduce asymmetry. Overall, the existence of the XBRL extension will help issuers carry out earnings evaluations if the level of corporate governance is weak. In Zamroni's (2018) research, companies that publish XBRL-based reporting also indicate the excellence of corporate governance.

Based on the above background, the purpose of this study is to determine that electronic financial disclosure that adopts XBRL and company characteristics (company growth, company size and profitability) affect value relevance and also to determine corporate governance as a moderating variable with electronic financial disclosure that adopts XBRL and company characteristics (company growth, company size and profitability) affect value relevance.

\section{Literature Review}

\subsection{Value Relevance}

Value relevance is an important point in disclosing financial statements and the accounting information contained therein for decision-makers. At present, the growth of the capital market depends on the credibility of financial information, and this financial information must have the ability to represent the company's overall performance (Permana, 2015). APB Statement No. 4 states that value relevance is relevant financial accounting information that influences economic decisions using financial accounting information. Financial reports must be prepared by following under generally accepted accounting standards. Ohlson (1995) in Permana (2015) explains that value relevance is measured based on the reciprocal relationship between accounting information, namely stock returns and market value, where the valuation model connects market prices and returns to different measurements of performance and financial position.

\subsection{Extensible Business Reporting Language (XBRL)}

XBRL is the language for electronic communication of business and financial data worldwide. It is a product of XBRL International, a non-profit consortium (www.xbrl.org). eXtensible Business Reporting Language (XBRL) is an XML language created specifically for business purposes. Cormier (2019) says that XBRL was introduced by Charles Hoffman in 1998. The basic idea of developing XBRL is to overcome interoperability constraints between platforms and speed up distribution and duplication of financial information for analysis and evaluation purposes. This open-source licensed XBRL language has a structure similar to the XML language. Even so, XBRL has a better function than XML. XBRL can accommodate the semantic needs of financial reporting that involve multiple linkages between one element and another in financial statements (multiple relationships). 


\subsubsection{Electronic Financial Disclosure Adopting Extensible Business Reporting Language (XBRL)}

XBRL has contributed to increasing the effectiveness and development of the role of electronic accounting disclosure according to Hanan (2015) cited in Benbouali and Berberi (2018). It consists of the following:

1. Provide financial statements

2. XBRL can read computer signs and apply financial information to business reports, by transforming reports into blocks of information that can be understood and processed through computer programs

3. Reduce costs

4. Provides technological independence by enabling automatic and reliable exchange of summary financial and non-financial information

5. Allows users to translate financial statement elements with accuracy and efficiency in more than one language

6. Allows the XBRL currency to be changed in the conversion mode the user wants and to the required currency, creating financial reports in more than one currency to help users make decisions as quickly as possible

7. XBRL allows analysis of a wide range of competing firms, making it more efficient for financial analysis

\subsection{Company Characteristics}

Company characteristics in Masrifa (2016) are one of the factors affecting firm value besides dividend policy. A characteristic is something specific owned by a company that can be developed by the company for its interests. Company characteristics are certain elements or characteristics that a company has that can be seen from various aspects, including the type of business, size of the company, level of profitability, level of liquidity, and ownership structure.

\subsubsection{Company Size}

Company size is a measure to decide the size of a company that is shown or valued by total assets, total profit, tax expense, total sales, and others (Brigham \& Houston, 2010). The greater the level of income, total assets, and total capital owned, the stronger the performance of the company. Company size is one of the variables that many financial analysts consider. Because the size of the company is quite influential in determining investors' financial decisions.

The size of the company in Sari et al.'s (2016) study explains that what is reflected in company performance is one measure to assess a company. Large companies are usually valued by the total assets they have and have better resources, one of which is a technology that supports the company's production activities to make it more efficient and effective (Sugandi \& Handojo, 2018). Brigham and Houston (2010), Harahap (2013), and Taliyang et al. (2011) state the size of a company size can be measured by the formula of the natural logarithm of total assets.

\subsubsection{Profitability}

All companies must have the same goal, namely, to make a profit. Profit or profitability is one of the benchmarks for the success of a company running its business. A good level of profitability at the company will be used as a signal so that the company is encouraged to disclose more information about the itself. This signal is a sign that the company has achieved its objectives (Anam Ousama et al., 2012).

In knowing the level of profitability, the company calculates it using the profitability ratio. The ratio will show the profit the company generates through sales and investment income (Kasmir, 2014). Sheridan et al. (2011) stated profitability serves to see the ability of the company to get a profit or investment return. Companies that have high profitability will attract investors so that the company value increases in the hope of getting high profits, so this is the basis for the logic of the theory of using ROA in this study.

\subsubsection{Company Growth}

Every company in carrying out a business activity must be oriented to the income that comes from the sales that have been achieved. Sales are the main source of income in a company and the income statement is always placed on the first line. If the products by the company have been sold to customers, the revenue will be reported as company sales.

Companies that want or are experiencing rapid growth have high costs. At the same time, companies should use equity as a source of financing to avoid agency costs (Hermuningsih, 2013). Companies will need more adequate disclosure to reduce information asymmetry when it is growing. Growth in sales is an important indicator that comes from a market acceptance of a product or service from the company, where sales that generate revenue for the company can be used as a measure of the growth rate of a company's sales. If the level of growth in a sale is high, then the company can be considered successful in executing its strategy towards marketing and selling its products.

\subsection{Corporate Governance}

In Sari et al. (2016), the agency theory suggests that corporate governance arises because of the separation between ownership and control of the company, which often 
creates agency problems. Corporate governance is needed in reducing agency problems between agents and principals. The implementation of good corporate governance is expected to increase transparency in financial reporting by following the basic principles of corporate governance itself. According to Mahardika (2018), one of the principles in good corporate governance (GCG) is transparency, where the application of these principles will produce better quality financial reports. Companies with GCG are estimated to have good financial reporting quality, so that their financial reports are more transparent and the information asymmetry for these companies decreases. One of the advantages of XBRL is that it increases the transparency of financial statements, so the adoption of XBRL is in line with GCG principles. Huynh (2020) find that corporate governance is a managerial term referred to as a mechanism of control consisting of the policies, procedures, practices and regulations. A good corporate governance practice can offer appropriate managerial tools to link stakeholders together such as directors, supervisors, shareholders and others by highlighting the principles of corporate governance - responsibility, independence, fairness, transparency, and accountability, which is aimed to restrain opportunistic and self-interest managers from behaving unethically and irresponsibly to stakeholders and society.

In William (2013), GCG itself has several definitions. According to the Forum for Corporate Governance in Indonesia (FCGI), GCG is a set of regulations governing the relationship between shareholders, company management, creditors, government, employees, and other internal and external stakeholders related to rights and obligations them or in other words a system that controls the company. The goal of GCG is to create added value for stakeholders (Wardhani, 2019). The benefits of the company implementing GCG are that the resources owned by the company's shareholders can be managed properly, efficiently and can be used solely for the benefit of the company's growth (value). For Rahman dan Khatun (2017), most of the researchers developed their selfstructured corporate governance index on the basis of code of best practice or governance guidelines, listing requirement, disclosure practices, corporate law or law applicable for companies, and previous literature to measure the corporate governance quality whereas few researcher used the corporate governance index provided by rating agencies.

Corporate governance also implies the existence of a structure of instruments to achieve goals and control performance. Good corporate governance can provide incentives for the board and management to achieve goals which are the interests of the company and shareholders must facilitate effective supervision to encourage companies to use resources more efficiently (Surya \& Yustiavandana, 2006). Rahman and Khatun (2017) find that corporate governance quality is defined as code of governance, rules, regulation, and best practices governance and developed to assess whether best governed or worst governed firms. Corporate governance is a system used to direct and monitor the firms (Cadbury Committee, 1992). In William (2013), to assess whether the principles of GCG implemented by companies are good or not, researchers used a scoring method called the FCGI Self-Assessment Checklist developed by FCGI.

\subsection{Previous Research Studies}

Muchlis (2019) shows that XBRL does not make financial reports more informative. Meanwhile, Razak (2019) found that the frequency of stock trading and ROA as control variables did not change when XBRL was implemented, while the implementation of XBRL was only carried out in 2015. However, size and dividends changed during the postXBRL period. Sari (2016) states that company characteristics have a negative effect on value relevance and corporate governance significantly reduces the effect of tax avoidance on value relevance. Tohang (2017) states that a decrease in the degree of ERV, as a proxy for lower information risk, can directly impact information quality, information efficiency and information transparency. By detecting information risks, stakeholders can be more aware of the need to ensure the quality of disclosure of reporting information.

Benbouli and Berberi (2018) say that a field study conducted to validate the questionnaire was distributed to several practitioners in countries that apply the "XBRL" language and there is a strong relationship between XBRL and financial market efficiency by helping them meet the requirements of creating information consistency, achieving corporate governance principles, increasing trading volume, increasing liquidity and price accuracy.

Illias (2015) shows that a starting point for CCM and other Malaysian regulators to consider the problems and challenges why such a scenario exists and then, provide a strategy to encourage these companies to adopt XBRL.

Cormier (2018) suggests that the emergence of the XBRL extension attracts financial analysts. Good corporate governance is positively related to voluntary XBRL extensions to increase the positive relationship between accounting earnings and stock prices. However, this positive relationship diminishes for firms with good governance, suggesting a substitution effect between XBRL extensions and corporate governance. Finally, it appears that the XBRL extension will be strategically related to earnings quality.

Mahardika (2018) assumes that, with the use of XBRL, it is expected that the quality of financial reporting will increase and can reduce information asymmetry. The results showed that the adoption of XBRL had an impact on reducing information asymmetry. Besides having a direct effect, corporate governance has also been shown to strengthen the negative effect of XBRL adoption on information asymmetry. 


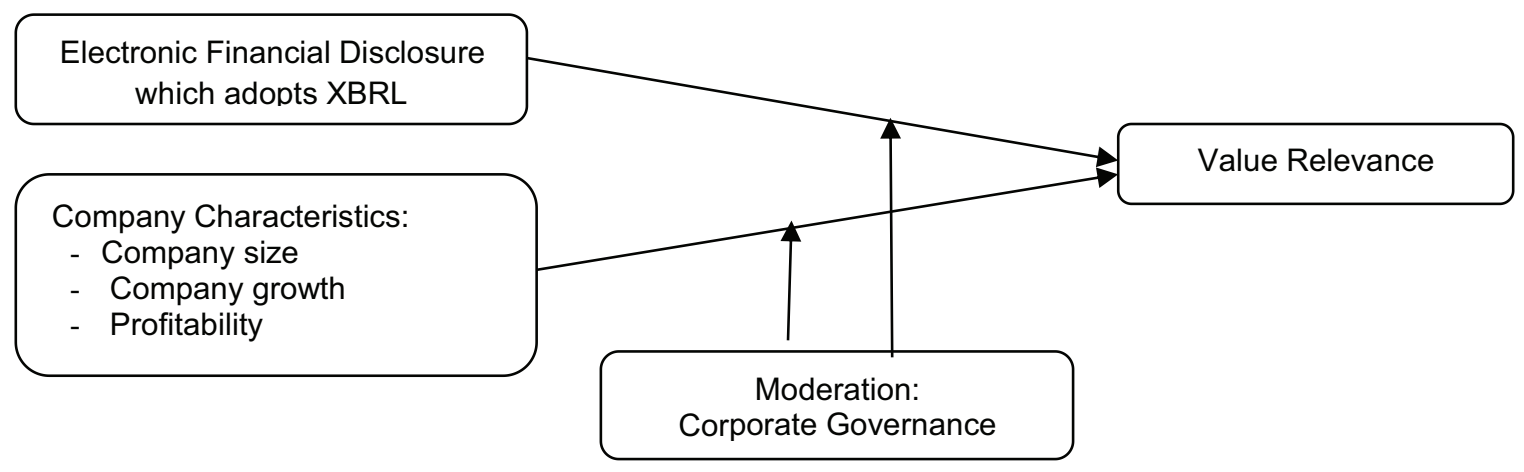

Figure 1: Research Framework

Hypotheses:

H1: Electronic financial disclosure that adopts XBRL is significantly and positively related to value relevance

H2: Firm size is significantly and positively related to value relevance

H3: Company growth is significantly and positively related to value relevance

H4: Firm profitability is significantly and positively related to value relevance

H5: Corporate governance as a moderating variable with electronic financial disclosure that adopts $X B R L$ is significantly and positively related to value relevance

H6: Corporate governance as a moderating variable with company characteristics (company size) is significantly and positively related to value relevance

H7: Corporate governance as a moderating variable with company characteristics (company growth) is significantly and positively related to value relevance

H8: Corporate governance as a moderating variable with company characteristics (profitability) is significantly and positively related to value relevance

\section{Research Methods}

\subsection{Research Design}

This research uses quantitative research methods, which is a type of systematic scientific research on phenomena and their relationships by collecting, processing, and analyzing data with statistical techniques, then making general conclusions to assess corporate governance and value relevance.

\subsection{Population and Sample}

The population is a generalization area consisting of objects or subjects that become certain quantities and characteristics set by the researcher for the study and then draw conclusions. The population in this study are all manufacturing companies listed on the Indonesia Stock Exchange from 2017 to 2018 totaling 166 companies. The sampling technique used purposive sampling method, namely, sampling selected according to the research criteria. The criteria are:

1. Manufacturing companies that publish fully audited financial statements by December 31 of the year (2017-2018).

2. Manufacturing companies that do not issue share prices.

3. Companies whose financial reports cannot be accessed or obtained in full by the researcher for the years of the study period

\subsection{Variable Operationalization}

Value relevance

The value relevance is reflected in the $\mathrm{R} 2$ indicator from the regression of stock prices with accounting earnings and earnings persistence. The basic regression equation between the company's stock price and accounting profit is shown below:

$$
\text { Pit }=\alpha+\beta \text { NIit }+ \text { eit }
$$

Earnings persistence is measured using the Lipe (1990) and Sloan (1996) model in Sutisna dan Ekawati (2016) as follows:

$$
\text { Earnings } \mathrm{t}+1=\alpha+\beta \text { Earnings } \mathrm{t}+\epsilon_{1}
$$

Electronic Financial Disclosure Adopting Extensible Business Reporting Language (XBRL)

$\mathrm{XBRL}$ is a dummy variable for XBRL adoption, which has a value of 1 if it is in the period after XBRL adoption, and will be worth 0 if it is in the period before adoption. 


\section{Company Characteristics}

a. Firm size

In this study, to determine the size of the company is to use the natural logarithm ( $\mathrm{Ln})$ of total assets.

b. Firm growth

In this study, growth is measured by sales growth as follows:

$$
\text { Sales Growth }=\frac{\text { Sales } t-\text { Sales } t-1}{\text { Sales } t-1}
$$

$$
\begin{aligned}
& \text { c. Profitability } \\
& \text { In measuring company profitability, researchers use } \\
& \text { Return on Assets (ROA). ROA is obtained by dividing } \\
& \text { operating income by total assets }
\end{aligned}
$$

\section{Corporate Governance}

Assessment of corporate governance in this study uses the Corporate Governance Self-Assessment Checklist. The self-assessment questionnaire can be obtained from the FCGI website. This questionnaire is weighted on 5 fields, namely:

a. Shareholder rights $(20 \%)$,

b. Corporate Governance policy (15\%),

c. Corporate Governance practices $(30 \%)$,

d. Disclosure (20\%) and

e. Audit function (15\%).

\subsection{Data Analysis Technique}

This study was conducted to examine the results of corporate governance and value relevance using secondary data. To test the hypotheses, this study uses SmartPLS version 3.3.2 as a powerful analytical method; because it can be applied to all data scales, the sample size used does not have to be large, nor does it require many assumptions. PLS can also be used to confirm a theory for proposition testing (Jaya \& Sumertajaya, 2008). The analysis technique used in this study is to measure predictions that have non-parametric properties, namely the measurement model (outer model) and structural model (inner model) (Ghozali, 2014).

\subsubsection{Multiple Regression Analysis}

In this study, linear regression analysis was used with moderating variables. Linear regression with moderating variables aims to determine the effect of moderating variables which will strengthen or weaken the relationship between the independent variable and the dependent variable, as follows:

$$
\begin{aligned}
\mathrm{VR} & =\beta 0+\beta 1 \mathrm{XBRL}++\beta 2 \mathrm{SIZE}+\beta 3 \mathrm{GROWTH} \\
& +\beta 4 \mathrm{PROFIT}+\beta 5|\mathrm{XBRL}-\mathrm{GCG}|+\beta 6|\mathrm{SIZE}-\mathrm{GCG}| \\
& +\beta 7|\mathrm{GROWTH}-\mathrm{GCG}|+\beta 8|\mathrm{PROFIT}-\mathrm{GCG}|+\varepsilon
\end{aligned}
$$

Description:

$\mathrm{VR}=$ Value Relevance

$\alpha=$ Intersep (constanta)

$\beta=$ Parameter (regression coefficient)

$\mathrm{XBRL}=\mathrm{XBRL}$ Adoption Value

SIZE $=$ Value of Company Size

GROWTH= Value of Company Growth

PROFIT $=$ Profitability Value

$|\mathrm{XBRL}-\mathrm{GCG}|=$ The Value of the Interaction between XBRL Adoption and Corporate Governance

$\mid$ SIZE-GCG $\mid=$ The Value of the Interaction between Company Size and Corporate Governance

$\mid$ GROWTH-GCG $\mid=$ The Value of the Interaction of

Company Growth and Corporate Governance

$\mid$ PROFIT-GCG $\mid=$ The Value of the Interaction of

Profitability and Corporate Governance

$\varepsilon=$ Disturbance error

\section{Results}

\subsection{Descriptive Statistics}

The population used in this study are manufacturing companies listed on the Indonesia Stock Exchange for the period 2017-2018. Manufacturing companies were chosen as objects in this study because they account for a large contribution to Indonesia's Gross Domestic Product (GDP). There are 102 manufacturing companies listed on the Indonesia Stock Exchange during the 2017-2018 period as research samples. Following are the results of the descriptive statistical analysis test obtained, namely:

The output results show that the value relevance (VR) has a minimum value of -0.85 and a maximum value of 6.96 , while the average obtained for the VR variable is 2.0988 or $209.88 \%$, so manufacturing companies are still classified as good in presenting its financial statement information. The standard deviation value is 1.55583 , this shows that the standard deviation value obtained is good enough.

The output results show that the minimum value of the XBRL variable is 0 and the maximum value is 1 , while the average value for this variable is 0.8873 or $88.73 \%$ of manufacturing companies have presented disclosures of financial statements based on Internet technology. The standard deviation value is 0.31706 showing that the standard deviation value obtained is still quite good.

The output results show that size has a minimum value of 25.22 and a maximum value of 33.47 , which means that company size is the measure used to decide the size of a company. The average value for this variable is 28.4834 and the standard deviation value is 1.58434 , which shows that the standard deviation value obtained is still quite good. 
Table 1: Descriptive Statistical Analysis Results

\begin{tabular}{|l|c|c|c|c|c|}
\hline & N & Minimum & Maximum & Mean & Std. Deviation \\
\hline VR & 204 & -.85 & 6.96 & 2.0988 & 1.55583 \\
\hline XBRL & 204 & .00 & 1.00 & .8873 & .31706 \\
\hline SIZE & 202 & 25.22 & 33.47 & 28.4834 & 1.58434 \\
\hline GROWTH & 204 & -.75 & 6.32 & .1414 & .49790 \\
\hline PROFIT & 204 & -21.20 & 104.66 & 10.0255 & 13.41960 \\
\hline GCG & 204 & .13 & .81 & .4539 & .12872 \\
\hline Valid N (listwise) & 202 & & & & \\
\hline
\end{tabular}

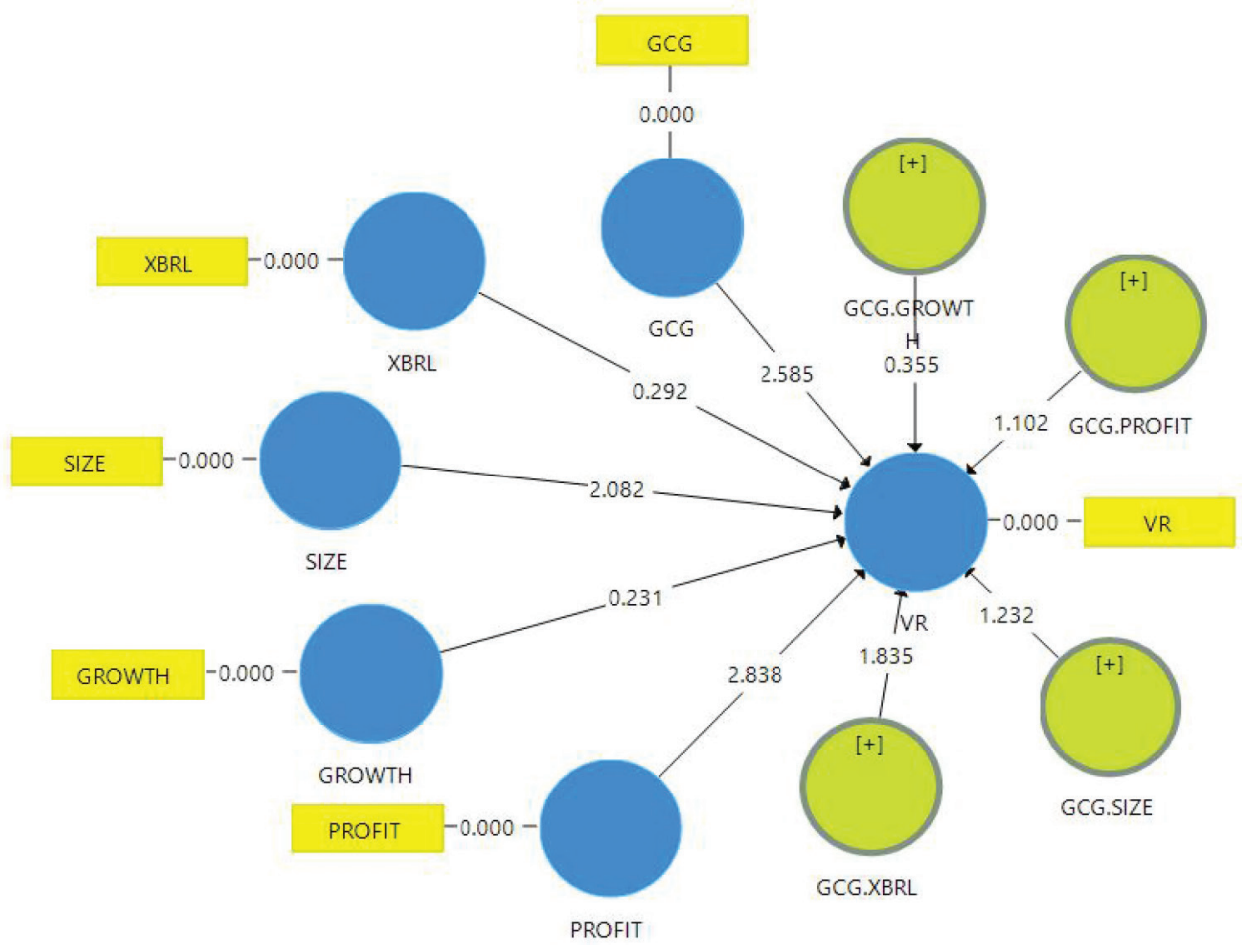

Figure 2: Formative Model

The growth variable has a minimum value of -0.75 and a maximum value of 6.32 , while the average value is 0.1414 with a standard deviation value of 0.49790 .

The results of profit variable has a minimum value of -21.20 and a maximum value of 104.66, while the average value of the profitability variable is 10.0255 , so the average manufacturing company can generate profits is still quite low and the standard

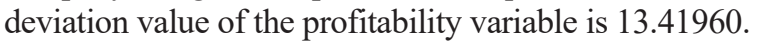

The output results show that corporate governance (GCG) with 204 sample companies has a minimum value of 0.13 and a maximum value of 0.81 , while the average obtained for the GCG variable is 0.4539 or $45.39 \%$, so manufacturing companies listed are still classified as good in disclosing its corporate governance information. The standard deviation value is 0.12872 , this shows that the standard deviation value obtained is good enough.

\subsection{Evaluation of Measurement (Outer) Model}

Testing the significance value of the first order factor using the bootstrapping procedure. Testing the measurement (outer) model is then carried out by testing the validity and reliability testing. Based on the Bootstrapping results, the image of the PLS Algorithm calculation is as follows: 
Table 2: P-Value Test Results

\begin{tabular}{|l|c|c|c|c|c|}
\hline & $\begin{array}{c}\text { Original Sample } \\
(\mathbf{O})\end{array}$ & $\begin{array}{c}\text { Sample Mean } \\
(\mathbf{M})\end{array}$ & $\begin{array}{c}\text { Standard } \\
\text { Deviation } \\
(\mathbf{S T D E V})\end{array}$ & $\begin{array}{c}\text { T Statistics } \\
(\text { (O/STDEV|) }\end{array}$ & P Values \\
\hline GCG $\rightarrow$ VR & 0,185 & 0,198 & 0,072 & 2,585 & 0,010 \\
\hline GCG.GROWTH $\rightarrow$ VR & 0,056 & 0,031 & 0,156 & 0,355 & 0,723 \\
\hline GCG.PROFIT $\rightarrow$ VR & 0,081 & 0,079 & 0,074 & 1,102 & 0,271 \\
\hline GCG.SIZE $\rightarrow$ VR & $-0,092$ & $-0,091$ & 0,074 & 1,232 & 0,219 \\
\hline GCG.XBRL $\rightarrow$ VR & $-0,136$ & $-0,145$ & 0,074 & 1,835 & 0,067 \\
\hline GROWTH $\rightarrow$ VR & 0,024 & $-0,003$ & 0,106 & 0,231 & 0,817 \\
\hline PROFIT $\rightarrow$ VR & 0,176 & 0,180 & 0,062 & 2,838 & 0,005 \\
\hline SIZE $\rightarrow$ VR & $-0,131$ & $-0,127$ & 0,063 & 2,082 & 0,038 \\
\hline XBRL $\rightarrow$ VR & $-0,017$ & $-0,011$ & 0,058 & 0,292 & 0,770 \\
\hline
\end{tabular}

\subsection{Interpretation of Hypothesis Testing Results}

P-Value (probability/significance value) is a test conducted to see the significance of a relationship between exogenous variables and endogenous variables (Riyanto \& Hatmawan, 2020). The following are the results of the P-Values and T-Statistics output in this study:

The significance of independent variables in this study indicated by a P-Value less than the standard of significance (P-Value $<0.05$ ), so it can be concluded that H1, H3, H5, H6, $\mathrm{H} 7$ and $\mathrm{H} 8$ are not accepted, but $\mathrm{H} 2$ and $\mathrm{H} 4$ are accepted.

\section{Discussion}

Electronic Financial Disclosure that adopts XBRL is significantly and positively related to Value Relevance

The results show Hypothesis 1 cannot be accepted. This does not support the studies by Graziano (2002) in Perdana (2011) that states that XBRL can create a more efficient financial statement presentation process with more reliable results, and has not been able to prevent redundancy and mismatches of data both input and output. As per Wu and Miklos (2004), XBRL can further increase the efficiency and effectiveness of accountants' work and it can facilitate the preparation of financial reports. Cormier's (2019) research concerning the incidence of XBRL extensions on the value relevance of earnings for stock market pricing finds that XBRL extensions enhance the positive relationship between earnings and stock price.

However, the results of this study are supported by Muchlis' (2019) research, which examines the impact of XBRL adoption in value relevance of earnings. The results suggest that early adopters of XBRL build value relevance for earnings; it is not supported by Razak's research (2019) showing that there is no difference in the pre- and postadoption of XBRL and the implementation of XBRL was only carried out on the Indonesia Stock Exchange in 2015, so XBRL trading information has not shown a positive response from investors. The results of this study indicate that the negative effect is not significant; companies that adopt XBRL show a low accounting relevance value that cannot be proven.

\section{Firm Size is significantly and positively related to Value} Relevance

The results show that Hypothesis 2 can be accepted, but with a negative effect that is contrary to the existing theory. The results of this study are not in line with Razak's (2019) research indicating that size affects the XBRL response, meaning that small companies respond to the existence of XBRL. Masrifa's research (2016) shows a significant effect on firm value, that the greater the size of the company, the faster the turnover of assets (the more effective the company is in generating profits from the use of its assets) and a positive signal for investors that the better the company's performance will increase investors' interest in investing, and in the end, the value of the company will increase. Hypothesis 1a (H1a) suggests that there is a positive relationship between firm size and the decision to adopt XBRL early. Hypothesis 1a is supported and indicate that a firm's decision to adopt XBRL depends on its size. Early adopters of XBRL have a larger size on average than those who do not.

Mahardika (2018) states that size affects information asymmetry negatively and significantly with a confidence level of $99 \%$. Large companies tend to have more frequent trading activity and receive the spotlight from the media and analysts, so that information asymmetry in large companies is lower than information asymmetry in small companies. The results in this study do not support previous research because they have a significant negative effect, which explains that the larger the size of the company that adopts XBRL has a low-value relevance relationship in disclosing information in financial statements and accounting information contained therein for decision-makers. 


\section{Company growth is significantly and positively related to Value Relevance}

The results show that Hypothesis 3 cannot be accepted. The results of the study are not in line with the theory that explains that companies that have high sales growth rates will be considered attractive by investors and are expected affect stock price movements so that company value will increase, and the results of Masrifa's (2016) research show insignificant influence on firm value. Hypothesis $1 \mathrm{~b}(\mathrm{H} 1 \mathrm{~b})$ suggests that there is a positive relationship between firms' growth and decisions of the firm to adopt XBRL. Hypothesis $1 \mathrm{~b}$ is not supported, indicating that there is no relationship between growth and early adopters of XBRL. For companies that are just growing, Zhang (2000) predicts that earnings and book value together can explain the value of equity.

This study shows there is an insignificant positive effect, meaning that the success of a project currently being carried out by a company is a sign that the company will be able to carry out other projects successfully even though it has a level of financial statement disclosure that reflects very little value relevance.

\section{Firm Profitability is significantly and positively related to Value Relevance}

The results show that Hypothesis 4 can be accepted. The results of this study support Masrifa's (2016) research, which shows a significant positive effect based on the signaling theory, where earnings can be used as an indicator to assess company performance. Companies with high-profit levels provide positive signals for rational investors so that they will invest their funds in companies that have a high level of asset use efficiency because the profits obtained are also high. Razak (2019) states that ROA testing for pre and postXBRL adoption indicates that the company's ROA has not changed at the time of XBRL adoption, there has been no positive response from investors. Zhang's research (2000) predicts that, with companies with low efficiency, the book value of equity is better able to explain the value of equity than earnings; this is consistent with the findings by Barth et al. (1998) that point to companies experiencing a decline in financial health.

In the results of this study, there is a significant positive effect that high profitability can explain the value relevance of financial statements well so that with the better the level of profitability the company can increase its operational activities with superior resources.

Corporate Governance as a moderating variable with electronic financial disclosure that adopts XBRL is significantly and positively related to Value Relevance

The results show that Hypothesis 5 can be accepted. The results of this study are not in line with $\mathrm{Haß}$ et al. (2014) in Mahardika (2018) stating that companies that have better
CG will tend to have more analysts who follow them, more forecast information results and tend to increase the accuracy of information on bad news compared to good news. This is because companies with good corporate governance have better transparency, so that analysts are more interested in following these companies. Companies that have adopted XBRL will have better information quality so that information asymmetry will be reduced. The effect of decreasing information asymmetry will be greater for companies that have better corporate governance. This is because companies with good corporate governance tend to have better quality and quantity of information presented. This result is in line with the research by Wang (2015) that looked at the effect of XBRL adoption on companies owned by the government and those not owned by the government in China.

The results of this study explain that the company is not yet optimal and there is still a lack of education regarding the importance of adopting XBRL, which is used for transmission and exchange of business information and, thus, improves the process of preparation, analysis and accuracy for various parties who provide and use business information, so that it also has an impact on not maximizing information disclosure corporate governance and value relevance.

Corporate governance as a moderating variable with company characteristics (company size) is significantly and positively related to Value Relevance

The results show that Hypothesis 6 cannot be accepted. The results of this study are in line with the research by Sari et al. (2016) that disclosure of corporate governance in annual reports can reduce information asymmetry to produce quality reports. This research is also not in line with the signaling theory, which emphasizes the importance of information issued by companies on investment decisions from parties outside the company. The characteristics of the company are one of the factors that influence the quality and value relevance of the information provided to investors. Companies that have large assets will be relatively more stable to generate profits compared to small companies. Naimah (2014) found that firm size is a proxy for differences in the information environment that will affect how price changes anticipate changes in earnings (Collins \& Kothari 1989). The stock prices of large companies are usually more informative than small companies. Liu et al. (2017) show that large firms may be in a better position to achieve superior firm performance due to their ability to garner efficiencies of scale. Also, large firms can develop higher-order capabilities to a greater extent due to the extra resources at their command. Much research evidence points to the existence of a direct relation between firm size and the adoption of information technologies, for example, confirms that larger firms often have superior financial and human resource 
capacity required to invest in high information capabilities. Dang et al. (2020) show that, when companies comply and implement CG well, they can make enterprises operate more effectively, reduce the agency cost of the business, thereby increasing Firm Value, both in book value and market value.

The results of this study explain that the size of a company has not been able to prove that it can provide useful information for decision making, it must meet the relevant quality that can meet the needs of users of financial statements in the decision-making process and may still be found unable to develop XBRL-based reporting so that the role of corporate governance is not optimal in making good decisions.

Corporate governance as a moderating variable with company characteristics (company growth) is significantly and positively related to Value Relevance

The results show that Hypothesis 7 cannot be accepted. The results of this study are not in line with the research by Sari et al. (2016). Large assets show that the company continues to experience growth. Companies that are constantly growing, easily attract capital, and this is a source of growth. Naimah (2014) says the success of a project that is currently being run by a company, will be a sign that the company will be able to carry out other projects successfully as well. Dang (2020) find that a properly-sized board can secure better coordination among members of the Board of Directors, which helps better supervision and management. However, as the business grows to a larger scale, operating in more areas, the CEO of the business needs to benefit from more consultations from the members of the Board of Directors to take key decisions.

The results of this study explain that there are allegations that there are still companies that have not maximally adopted XBRL and have low growth rates and still are unable to run projects successfully. This is supported by not disclosing indicators of corporate governance properly resulting in accounting information reflected in the financial statements of several manufacturing companies, which make different decisions for users to predict the impact of past, present, and future events, to confirm or correct expectations.

Corporate governance as a moderating variable with company characteristics (profitability) is significantly and positively related to Value Relevance

The results show that Hypothesis 8 cannot be accepted. Sari et al. (2016) show that information on profit or profitability in companies will be responded positively by investors. Profitable companies will generally develop in the future. The information that was widely available yearround on large firms at the time of earnings announcements resulted in the market being less reacting. Better information quality indicates that the level of information disclosure by the company is better, especially with companies that adopt XBRL
(Mahardika, 2018). Large companies prefer methods that delay reporting of earnings and have greater sensitivity value in making direct transfers of wealth through taxation systems and political costs. Through high profitability, the company can make the main concern of shareholders and creditors, so that it can disclose corporate governance information properly and provide a qualitative value of accounting information in financial reports (Gandasari \& Herawaty, 2015). Huynh (2020) indicates that corporate governance serves as a good controlling mechanism to diminish unethical behaviors by managers in manipulating reported earnings and to enhance social responsible actions by companies.

The results of the study explain the tendency of manufacturing companies not to show a high level of profitability and not to show the credibility of the company, which can result in company performance during the current period having an impact on investors' judgment to invest or not.

\section{Conclusions}

Observing the movement of XBRL adoption, it is important to understand that the occurrence of value relevance is not simple to detect, which several factors may affect, including the transparency of information as well as the quality of the information. This study proves that XBRL has not a significant negative effect on value relevance, the negative effect is significant on size of value relevance; the positive effect is not significant on growth of value relevance, but has a significant positive effect on profit of value relevance. The moderating variable of corporate governance has an insignificant effect on all hypotheses because the application of XBRL was only implemented on the Indonesia Stock Exchange in 2015, so XBRL trading information and its disclosures have not shown a positive response from investors and industry. The application of corporate governance is also not able to strengthen company relationships adopting XBRL and company characteristics on value relevance resulting in poor and less optimal decision-making and not providing good performance value to manufacturing companies.

For future research, it will be beneficial to investigate the period pre- and post-XBRL adoption and includes more variable such as asymmetry information and information risk to see profound impacts of the XBRL adoption against value relevance.

\section{References}

Asnawi, S. K., \& Wijaya, C. (2005). Financial Research: Empirical Tests. Jakarta, Indonesia: Gramedia Pustaka Utama.

Anam Ousama, A., Fatima, A., \& Rashid Hafiz - Majdi, A. (2012). Determinants of intellectual capital reporting. Journal of 
Accounting in Emerging Economies, 2(2), 119-139. https://doi. org/10.1108/20421161211229808

Benbouali, K., \& Benberi, M. A. (2018). The Importance of Introducing Electronic Accounting Disclosure Using the XBRL Language in Activating the Algerian Stock Market. Journal of Accounting, Finance, and Auditing Studies. 4(1), 40-58. https:// www.um.edu.mt/library/oar//handle/123456789/27389

Brigham, E. F., \& Houston, J. F. (2010). Fundamentals of Financial Management (11th Edition,). Jakarta, Indonesia: Publisher Salemba Empat.

Cahyadi, I. F. (2019). The Role of Accounting Information Systems and the Challenges of the Accountant Professional in the Era of the Industrial Revolution 4.0 (A Phenomenology Study). AKTSAR: Journal of Islamic Accounting, 2(1), 69. https://doi. org/10.21043/aktsar.v2i1.5497

Cormier, D., Dufour, D., Luu, P., Teller, P., \& Teller, R. (2019). The Relevance of XBRL Voluntary Disclosure for Stock Market Valuation: The Role of Corporate Governance. Canadian Journal of Administrative Sciences, 36(1), 113-127. https://doi. org/10.1002/cjas. 1483

Dang, H. N., Pham, C. D., Nguyen, T. X., \& Nguyen, H. T. T. (2020). Effects of corporate governance and earning quality on listed Vietnamese firm value. Journal of Asian Finance, Economics and Business, 7(4), 71-80. https://doi.org/10.13106/ jafeb.2020.vol7.no4.71

Gandasari, I., \& Herawaty, V. (2015). Effect of Company Characteristics on Income Smoothing with Good Corporate Governance as a Moderation Variable. Journal of Master of Accountancy Trisakti. 2(1), 73-94

Ghozali, I. (2014). Structural Equation Modeling, Alternative Methods with Partial Least Square (PLS) (4th ed.). Semarang, Indonesia: Diponegoro University Publishing Agency.

Harahap, S. S. (2013). Critical Analysis of Financial Statements (11 ${ }^{\text {th }}$ ed.). Jakarta, Indonesia: Rajawali Press.

Hermuningsih, S. (2013). Effect of Profitability, Growth Opportunity, Capital Structure on Firm Value in Public Companies in Indonesia. Bulletin of Monetary Economics and Banking, 16(2), 128-148. https://doi.org/10.21098/bemp.v16i2.27

Huynh, Q. L. (2020). A triple of corporate governance, social responsibility and earnings management. Journal of Asian Finance, Economics and Business, 7(3), 29-40. https://doi. org/10.13106/jafeb.2020.vol7.no3.29

Ilias, A., \& Ghani, E. K. (2015). Examining the Adoption of Extensible Business Reporting Language among Public Listed Companies in Malaysia. Procedia Economics and Finance, 28(April), 32-38. https://doi.org/10.1016/s22125671(15)01078-3

Jaya, I. G. N. M., \& Sumertajaya, I. M. (2008). Modeling of Structural Equations with Partial Least Square. In: National Mathematics and Mathematics Education 2008 (pp. 118-132).

Kasmir. (2014). Introduction to Financial Management. Jakarta, Indonesia: Kencana Prenada Media Group
Liu, C., Luo, X., \& Wang, F. L. (2017). An empirical investigation on the impact of XBRL adoption on information asymmetry: Evidence from Europe. Decision Support Systems, 93(2017), 42-50. https://doi.org/10.1016/j.dss.2016.09.004

Mahardika, S. A., \& Harahap, S. N. (2018). Analysis of XBRL's Adoption's Impact on Information Asymmetry, with Corporate Governance as Moderating Variable. Indonesian Journal of Accounting and Finance, 15(2), 216-235. http://dx.doi. org/10.21002/jaki.2018.12

Masrifa, A. Y. A. (2016). Company Characteristics to Firm Value, with Dividend Payout Ratio as an Intervening Variable. Advance, 3(1), 1-19.

Muchlis, F., Primadyan, M., R. Shauki, E., \& Diyanty, V. (2019). Examining XBRL Early Adopters: A Study of Determinants and Value Relevance. Advances in Economics, Business and Management Research, 89(Apbec 2018), 267-274. https://doi. org/10.2991/apbec-18.2019.35

Naimah, Z., \& Mukti, N. A. (2019). The influence of the audit committee's and company's characteristic on intellectual capital disclosure. Asian Journal of Accounting Research, 4(2), 170-180. https://doi.org/10.1108/ajar-05-2019-0036

Perdana, A. (2011). Extensible Business Reporting Language (XBRL): Implications for Financial Reporting Paradigms and Supply Chains. In: National Seminar on Information Technology Application 2011 (SNATI 2011) (pp. 14-20).

Permana, Aryo Bimo Setya. (2015). The Effect of Value Relevance on Investor Decisions. AKUNESA Accounting Journal, 3(2), $1-20$

Pujisari, Y., \& Biyanto, F. (2019). Awareness and Understanding of Educator Accountants towards XBRL. INVENTORY: Journal of Accounting, 3(1), 33-46.

Rahman, M. M., \& Khatun, N. (2017). Quality of Corporate Governance: A Review from the Literature. Journal of Asian Finance, Economics and Business, 4(1), 59-66. https://doi. org/10.13106/jafeb.2017.vol4.no1.59

Razak, L. A., Pontoh, G. T., \& Yamin, M. (2019). XBRL Adoption of Investor Trading Behavior on the Indonesia Stock Exchange. Nabelo Account Journal: Neutral, Accountable, Objective Accounting Journal, 1(2). https://doi.org/10.22487/ j26223090.2019.v1.i2.11884

Riyanto, S., \& Hatmawan, A. A. (2020). Research Methods : Research Quantitative Research in the fields of Management, Engineering, Education, and Experiments. Sleman, Indonesia: Deepublish Publisher

Sari, E. P., Handajani, L., \& AM, S. (2016). Corporate Governance and the Value Relevance of Tax Avoidance: Empirical Evidence from the Indonesian Capital Market. Journal of Accounting and Business Dynamics, 3(2), 33-48. https://doi.org/10.24815/jdab. v3i2.5385

Sheridan, T., Keown, A. J., \& Martin, J. D. (2011). Financial Management Principles and Applications (11 ${ }^{\text {th }}$ ed.). New York, NY: Pearson. 
Simanjuntak, P. N. M. (2017). Analyze to the Role Extensible Business Reporting Language (XBRL) to Improve the Accuracy of Tax Reporting. Parahyangan International 3rd Accounting \& Business Conference, 8(9), 1-58.

Sutisna, H \& Ekawati, E. (2016). Income Persistency in The Level of Companies and Industries Association with Cash and Accrual Flow Volatilities. In: XIX National Symposium on Accounting, Lampung, Indonesia.

Taliyang, S. M., Latif, R. A., \& Mustafa, N. H. (2011). The determinants of Intellectual Capital Disclosure among Malaysian Listed Companies. International Journal of Management and Marketing Research, 4(3), 25-33.

Tohang, V., \& Lan, M. (2017). The Impact of Adoption of XBRL on Information Risk in Representative Countries of Scandinavian Region. Journal of Finance and Banking, 21(4), 515-526. https://doi.org/10.26905/jkdp.v21i4.1525

Wang, Z. (2015). Financial Reporting With XBRL and Its Impact on the Accounting Profession. Thesis, 1-284.
Wardhani, Faradina Inda. (2019). Self-Assessment on the Implementation of Good Corporate Governance at PT Bank Mandiri (Persero) Tbk. INTEGRA, 9(2), 125-143

William, L., Pratama, A., \& Mustamu, R. H. (2013). Application of Good Corporate Governance Principles in Family Companies: Descriptive Study of Food Distributors. Jurnal Manajemen Bisnis, 1(1), 1-11.

Wu, J., \& Vasarhelyi, M. A. (2004). Business Intelligence Techniques. Business Intelligence Techniques, (April 2015). https://doi.org/10.1007/978-3-540-24700-5

Zamroni, M., \& Aryani, Y. A. (2018). Initial Effects of Mandatory XBRL Adoption across the Indonesia Stock Exchange's Financial Information Environment. Journal of Finance and Banking, 22(2), 181-197. https://doi.org/10.26905/jkdp. v22i2.2092.

Zhang, X.-J. (2000). Conservative accounting and equity valuation, Journal of Accounting and Economics, 29(1), 125-149. 